\title{
Survey of Different Locations for Prevalence of Wilt Disease of Gladiolus
}

\author{
S.S. Munde ${ }^{1 *}$, D.N. Dhutraj, P.B. Khaire and D.G. Hingole \\ ${ }^{1}$ Department of Plant Pathology, Vasantrao Naik Marathwada Krishi Vidyapeeth, Parbhani \\ ${ }^{2}$ Department of Plant Pathology, College of Agriculture, Badnapur, India \\ *Corresponding author
}

\begin{abstract}
A B S T R A C T
Keywords

Survey, Gladiolus wilt, Fusarium oxysporum f. sp. gladioli, Incidence

Article Info

Accepted:

12 April 2019

Available Online:

10 May 2019

\section{Introduction}

Gladiolus (Gladiolus hybridus L.) is one of the such cut flower which has tremendous potential in the international and national market with a trade value of more than 98.2 million dollars (Anonymous 2016). In India gladiolus is mostly grown in state like Uttar Pradesh, West Bengal, Orissa, Chattisgarh, Haryana, Maharashtra, Uttarkhand, Karnataka, Andhra Pradesh and Sikkim (Anonymous 2016). In Marathwada region of Maharashtra gladiolus is being grown under several units and open cultivation with a production of 9.8 lakh cut flowers per annum, valuing 148 lakh rupees, as per 2015-16 estimates (Anonymous, 2016). At present the
\end{abstract}

area under cut flower in India 80 thousand ha. with 472 thousand tonnes production (Anonymous 2016).

The low productivity of gladiolus is attributed to productivity constrains. Among these biotic factor particularly diseases play an important role in the limiting the production of gladiolus. Gladiolus is affected by a number of diseases which are caused by fungi, bacteria, nematodes and viruses. The corm rot of wilt of gladiolus is one of the most important fungal diseases caused by Fusarium oxysporum f.sp. gladioli (Mirza and Shakir 1991). The literature reveals that the yield losses caused due to wilt of gladiolus become very severe now a day and causes $60-70$ per 
cent plant mortality. According to Bruhm (1995) and Protstnko (1958) above 35\% annual loss was estimated in Germany and 60 - $80 \%$ annual loss in Russia. In India 7.12$64.23 \%$ disease incidence was recorded at Himachal Pradesh. This fungus has been distributed throughout the world and particularly prevalent in cool as well as warm climate and significant loss was reported.

The wilt of gladiolus caused by Fusarium oxysporum f. sp gladioli is a serious problem in open as well as protected cultivation especially polyhouse. The information are lacking on study and their management in protected condition.

\section{Materials and Methods}

\section{Survey for wilt of gladiolus in Aurangabad District}

Survey was conducted in polyhouse units and open field, gladiolus growing of Aurangabad district to record the incidence of wilt. From each Taluka / Block four villages were chosen for recording incidence of disease. The disease incidence was recorded by counting the number of plants showing wilt disease symptoms such as corm rotting, yellowing of leaves, wilt of plants and the total number of plants present. In each field rows were selected randomly and the number of plants showing typical wilt symptoms and total number of plants were recorded. Percent disease incidence was calculated by using formula given by Mayee and Datar (1985).

Percent disease incidence $=$

No. of affected Plant

Total No. of Plant

During survey characteristic symptoms of wilt disease, variety, method of corm storage, plant protection measure adopted by farmer etc. were recorded and also samples were collected for isolation of pathogen.

\section{Results and Discussion}

\section{Prevalance of wilting of gladiolus under protected cultivation (polyhouse) in different locations at Aurangabad district of Marathwada region}

A survey for the incidence of wilt of gladiolus ( $F$. oxysporum f.sp. gladioli) was carried out at 12 locations comprising five tahsils of Aurangabad district during 2016-17 and results are presented in (Table 1).

Data presented in Table 1 showed that incidence of wilt of gladiolus varied from 05.00 to 10.00 per cent. The highly prone areas of wilt of gladiolus under polyhouse in Aurangabad district were Naygaon and Bhoyagaon (10.00\% each), followed by Fardapur (09.50\%). The lowest disease incidence was recorded at Sultanpur $(05.00 \%)$ and Borgaon $(06.00 \%)$ locations in Paithan tahsil of Aurangabad district. The average district mean per cent incidence of wilt of gladiolus under protected condition (polyhouse) in Aurangabad was recorded 07.95 per cent.

\section{Tahsil wise mean disease incidence}

The data from the (Table 1 and Fig.1) revealed the mean disease incidence observed in five tahsils of Aurangabad district ranged from 06.00 to 9.75 per cent. However, the highest mean disease incidence was found in Soygaon tahasil (09.75\%), followed by Fulambri (09.00\%), Aurangabad and Kannad $(07.50 \%$ each) and the lowest mean incidence was reported in Paithan tahasil 06.00 per cent. The highest disease incidence in Nayagon and Bhoyagaon village could be due to using infected corms for sowing. 
Prevalance of wilting of gladiolus in open field of different locations at Aurangabad district of Marathwada region

A survey for the incidence of wilt of gladiolus (F. oxysporum f.sp. gladioli) was carried out at 18 locations comprising six tahsils of Aurangabad district during 2016-17. The gladiolus open fields were surveyed at seedling stage and results are presented in (Table 2 and PLATE I)

Data presented in Table 2 showed that incidence of wilt of gladiolus varied from 08.00 to 21.00 per cent. The highly prone areas of wilt of gladiolus in Aurangabad district were Dabhadi (21.00\%), followed by Bramhni and Wadi $(20.50 \%)$ each, Ajantha $(20.00 \%)$. The lowest disease incidence was recorded at Tongaon $(08.00 \%)$ and Kanchanwadi $(08.50 \%)$ locations in Aurangabad tahsil of Aurangabad district. The average district mean percent incidence of wilt of gladiolus in open field at Aurangabad was recorded 15.29 per cent.

\section{Tahsil wise mean disease incidence}

The data from the (Table 2, Fig.2 and PLATE I) revealed the mean disease incidence observed in six tahsils of Aurangabad district ranged from 10.12 to 20.75 per cent. However, the highest mean disease incidence was found in Kannad tahasil (20.75), followed by Soegaon (19.32\%), sillod $(18.10 \%)$, Paithan $(15.16 \%)$ and Fulambri (14.90\%).The lowest mean incidence was reported in Aurangabad tahasil 10.12 per cent.

The highest disease incidence in Kannad tahasil of Bramhani and Dabhadi village could be due to presence of high soil $\mathrm{pH}$, storage condition and using infected corms for planting. The same opinion was also expressed by Harrison (1962), Grimals skaya (1978), Gopal et al., (2000).

Table 1 Per cent disease incidence of wilt of gladiolus under protected cultivation (polyhouse) at Aurangabad district

\begin{tabular}{|c|c|c|c|c|}
\hline Sr.No & District & Tahsil & Village & Disease Incidance \% \\
\hline \multirow[t]{17}{*}{1} & \multirow[t]{17}{*}{ Aurngabad } & \multirow[t]{3}{*}{ 1.Aurangabad } & Adgaon & 7.00 \\
\hline & & & Shendra & 7.50 \\
\hline & & & Karmad & 8.00 \\
\hline & & \multicolumn{2}{|l|}{ Mean } & 7.50 \\
\hline & & \multirow[t]{2}{*}{ 2.Soegaon } & Fardapur & 9.50 \\
\hline & & & Naygaon & 10.00 \\
\hline & & \multicolumn{2}{|l|}{ Mean } & 9.75 \\
\hline & & \multirow[t]{2}{*}{ 3.Fulambri } & Nimkheda & 8.00 \\
\hline & & & Bhoyagaon & 10.00 \\
\hline & & \multicolumn{2}{|l|}{ Mean } & 9.00 \\
\hline & & \multirow[t]{3}{*}{ 4.Paithan } & Borgaon & 6.00 \\
\hline & & & Pimpalwadi & 7.00 \\
\hline & & & Sultanapur & 5.00 \\
\hline & & \multicolumn{2}{|l|}{ Mean } & 6.00 \\
\hline & & 5. Kannad & Kolewadi & 8.00 \\
\hline & & & Dabhadi & 7.00 \\
\hline & & \multicolumn{2}{|l|}{ Mean } & 7.50 \\
\hline \multicolumn{4}{|c|}{ Average district mean } & 7.95 \\
\hline
\end{tabular}


Table.2 Per cent disease incidences of wilt of gladiolus in open field at Aurangabad district

\begin{tabular}{|c|c|c|c|c|}
\hline Sr.No & District & Tahsil & Village & Disease Incidance \% \\
\hline \multirow{23}{*}{1} & \multirow{23}{*}{ Aurangabad } & \multirow[t]{5}{*}{ 1.Aurangabad } & Phardadi & 10.00 \\
\hline & & & Toangaon & 8.00 \\
\hline & & & Kanchanwadi & 8.50 \\
\hline & & & Shendra & 9.10 \\
\hline & & & Karmad & 15.00 \\
\hline & & \multicolumn{2}{|l|}{ Mean } & 10.12 \\
\hline & & \multirow[t]{3}{*}{ 2.Sillod } & Ajantha & 20.00 \\
\hline & & & Bodwad & 19.20 \\
\hline & & & Lihakhedi & 15.10 \\
\hline & & \multicolumn{2}{|l|}{ Mean } & 18.10 \\
\hline & & \multirow[t]{2}{*}{ 3.Soegaon } & Fardapur & 18.15 \\
\hline & & & Wadi & 20.50 \\
\hline & & \multicolumn{2}{|l|}{ Mean } & 19.32 \\
\hline & & \multirow[t]{3}{*}{ 4.Fulambri } & Nimkheda & 13.80 \\
\hline & & & Bhoyagaon & 14.50 \\
\hline & & & Girsalwadi & 16.40 \\
\hline & & \multicolumn{2}{|l|}{ Mean } & 14.90 \\
\hline & & \multirow[t]{3}{*}{ 5.Paithan } & Pusegaon & 12.10 \\
\hline & & & Pimpalwadi & 15.80 \\
\hline & & & Sultanapur & 17.60 \\
\hline & & \multicolumn{2}{|l|}{ Mean } & 15.16 \\
\hline & & \multirow[t]{2}{*}{ 6. Kannad } & Bramhani & 20.50 \\
\hline & & & Dabhadi & 21.00 \\
\hline & & \multicolumn{2}{|l|}{ Mean } & 20.75 \\
\hline \multicolumn{4}{|c|}{ Average district mean } & 15.29 \\
\hline
\end{tabular}

Fig.1 Tahsils wise disease incidence of wilting on gladiolus under protected condition

(Polyhouse) at Aurangabad districts

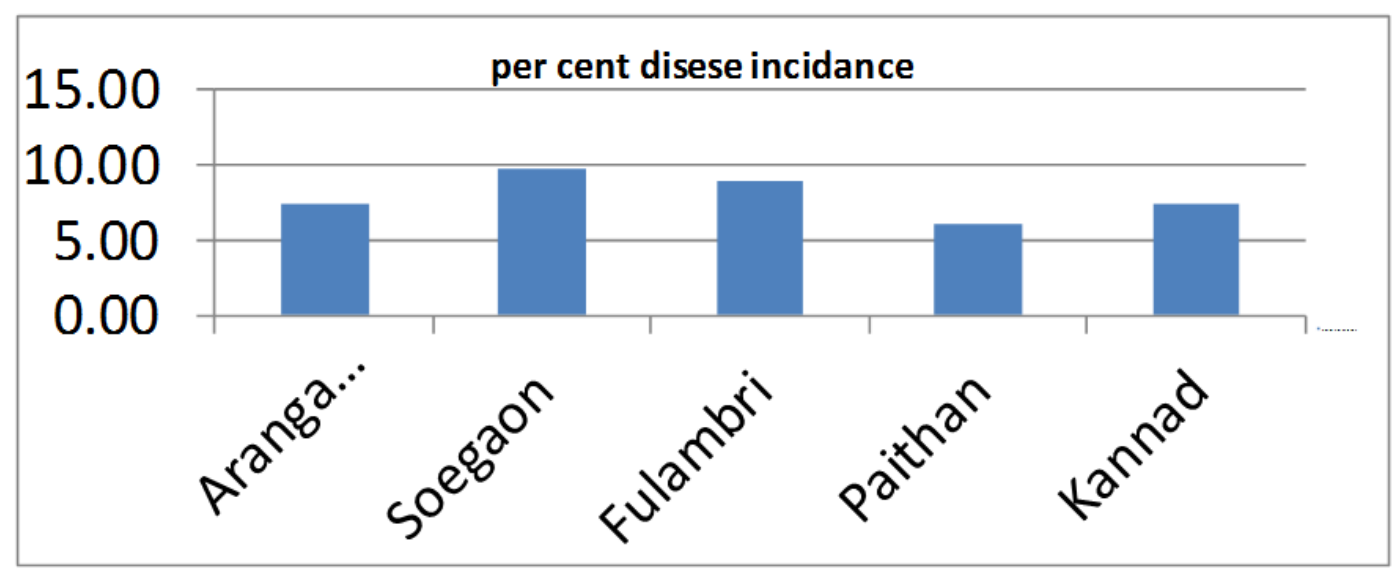


Fig.2 Tahsils wise disease incidence of wilting on gladiolus in open field at Aurangabad districts

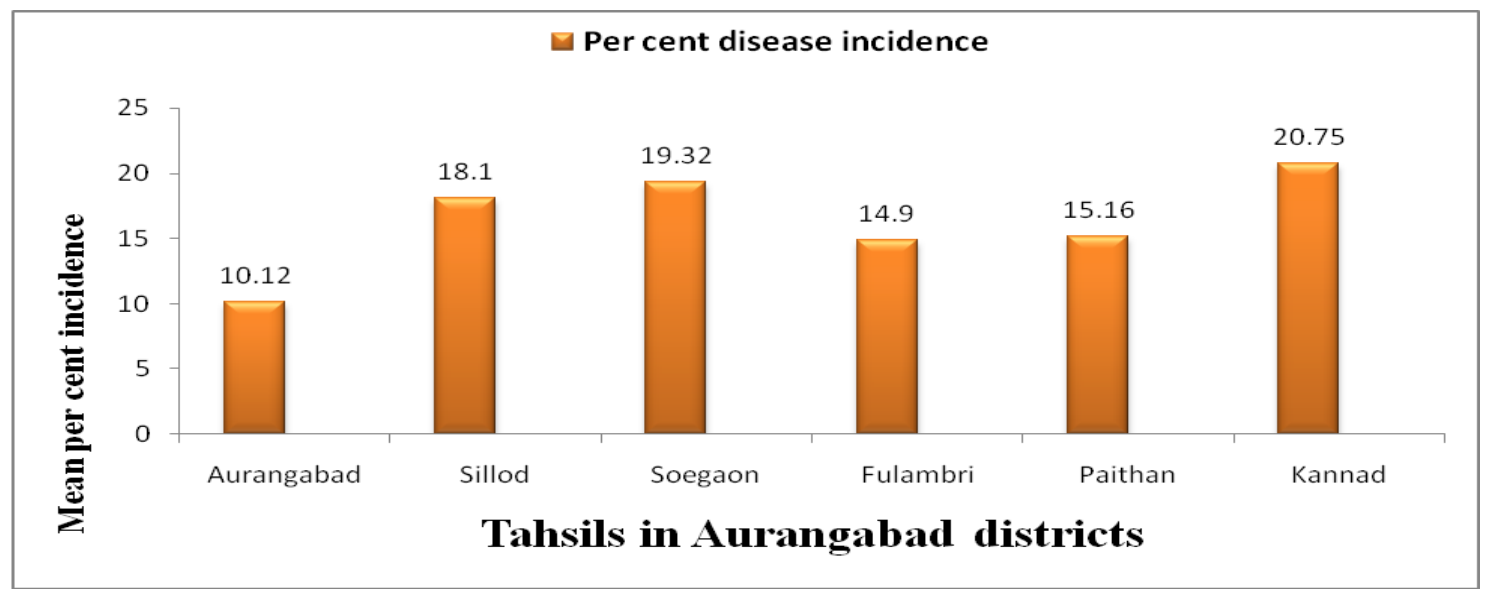

Plate.1 Survey of Gladiolus in Aurangabad District

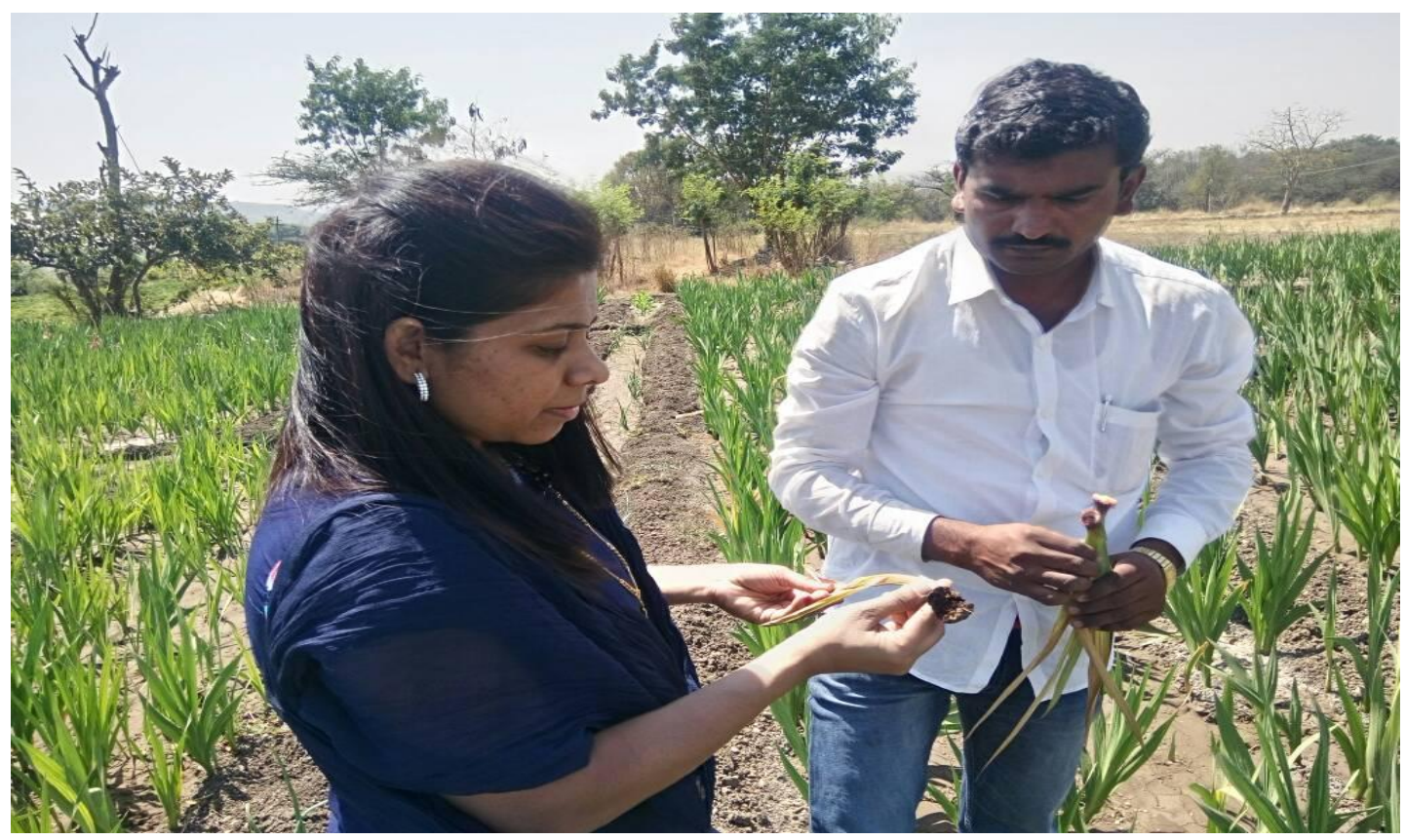

\section{References}

Anonymous, (2016). Horticulture Crop Statistics of Maharashtra State - At a Glance.

Bruhm,(1995). Untersuchungenuber die Fusarium krankheit gladiolus phytopatho 25:1-38.

Chen, L.Z.; Gan, X.B.; Song, J.Y.; Gu,W. (1994). [A study on gladiolus root rot]. Journal of Sanghai. Agricultural
College, 12 (4): 240-246.

Dolar, F. S. (1996). Evaluation of some chickpea cultivars for resistance to Ascochytarafic (poss.) Labr. Fusarium oxysporum and $F$. solani in Turkey. J. Turkash Phytopath.24: 15-20.

Gopal, K., Reddy., M. R. S., Reddy, B. C., Rao, A. R., Madhavi, M. and Venkatraman K. T. (2000). Citrus decline in Andhara Pradesh- causes and their management. Paper presented in 
International symposium on Citriculture held at Nagpur, November 23-27, (1999) at Nagpur, India, 107.

Grimal skaya, S. I. (1978). Detection of resistance in daughter bulbs of gladiolus to

Fusarium disease on artificially infested ground.Byulleten'Vsesoyuznogoodrena LeninaI Ordena. Druzhby Narodov Instituta Rastenievodstva Imeni NI, 91: 1012-1013.

Harrison D.E. (1962). Fusarium yellow and corm rot of gladiolus J. Agric Viet, 60: 377-387

Hsieh, S.P.Y. (1985). Ecology and control of Gladiolus Fusarium wilt. Plant Protection. Bulletin, Taiwan, 27 (3): 247-256.

Kumar, Jeetendra (2014). Studies on survey of Fusarium wilt of pea in Eastern Uttar Pradesh Int. J. of Life Sciences. 2 (4) 359-362.

Massey, M. (1926). Fusarium rot of gladiolus corms. Phytopathology, 16: 509-523.

Mayee, C.D and Datar, V.V. 1986. Phytopathometry. Tech. Bull.-1 Marathwada Agric. Univ. Parbhani. pp: 66.

Me. Culloch, L. (1944). A vascular disease of gladiolus caused by Fusarium.
Phytopathology, 34: 263-287.

Mirza, J. H. and Shakir, A. S. (1991). First report of fungal pathogens of gladiolus from Pakistan, Pakistan $J$. Pytopath.3: 1-2, $74-76$.

Moore, W.C. (1939). Diseases of Bulbs. Bull. Minist. Agric. Fish. Fd, London, 117: IV 176.

Pryal, W.A. (1909). Diseases among gladioli. Rural New Yorker, 68: 1009.

Readdy, M.V., U.A. Baw., U.M. Hein., U.K.Moe., S.C.S. Sethi (1991). Survey of chickpea disease in Myanmar. International chickpea and Pigeon pea News letter, 26:46-47.

Sudarshanrao, A. N. (1975). Survey, surveillance and forecast in plant protection. Kisan World, 2: 43 - 44.

Thaware, D. S., Kohire O. D. and Gholve V. M. (2015). Survey of chickpea wilt (Fusarium oxysporum f. sp. ciceri) disease in Marathwada region of Maharashtra state. Advance Res. J. Improvement 6: 134-138.

Zemouli- Benfreha, F., Djamel-eddine, $\mathrm{H}$ and A. Merzouy, (2013). Fusarium wilt of chickpea incidence. African J. Agri. Res.. 9 (1) p168s-175.

\section{How to cite this article:}

Munde, S.S., D.N. Dhutraj, P.B. Khaire and Hingole, D.G. 2019. Survey of Different Locations for Prevalence of Wilt Disease of Gladiolus. Int.J.Curr.Microbiol.App.Sci. 8(05): 1513-1518. doi: https://doi.org/10.20546/ijcmas.2019.805.174 